\title{
Komposisi dan Tutupan Kanopi Vegetasi Mangrove di Perairan Bakauheni, Kabupaten Lampung Selatan
}

\author{
Ilham Kuncahyo*, Rudhi Pribadi, Ibnu Pratikto \\ Departemen IImu Kelautan, Fakultas Perikanan dan Ilmu Kelautan, Universitas Diponegoro \\ Jl. Prof. H. Soedarto S.H, Tembalang, Semarang, Jawa Tengah 50275 Indonesia \\ *Corresponding author, e-mail : ilhamkuncahyo1@gmail.com
}

\begin{abstract}
ABSTRAK: Kondisi kesehatan vegetasi mangrove yang berada di daratan dan pulau - pulau kecil sangat penting dalam menjaga keseimbangan ekosistem pesisir dan laut. Perbedaan kondisi tumbuh mangrove dapat mempengaruhi dinamika perubahan vegetasi dan tutupan kanopi mangrove. Penelitian ini bertujuan untuk menganalisis struktur, komposisi dan tutupan kanopi mangrove di Perairan Bakauheni, Kabupaten Lampung Selatan. Metode yang digunakan dalam penelitian ini yaitu metode deskriptif. Penentuan titik atau stasiun sampling dengan menggunakan metode purposive sampling. Metode pengambilan data vegetasi mangrove dengan metode plot sampling dan pengambilan data tutupan kanopi mangrove dengan metode hemispherical photography. Penelitian ini dilakukan di 4 lokasi yaitu Desa Kramat (DK), Desa Muara Bakau (DMB), Pulau Rimau Balak (PRB), dan Pulau Kandang Balak (PKB) yang terdiri dari 4 stasiun penelitian. Hasil penelitian menunjukkan bahwa kawasan Perairan Bakauheni yang terdiri dari 4 lokasi peneltiian ditemukan 14 spesies mangrove di dalam plot dan di luar plot penelitian. Nilai Kerapatan mangrove berkisar 966-1634 ind/ha. Nilai Indeks Keanekaragaman ( $\left.H^{\prime}\right)$ dan Keseragaman (J') di lokasi penelitian termasuk dalam kategori rendah. Hasil persentase tutupan kanopi mangrove termasuk kategori padat berkisar $72,04 \pm 13,18 \%-86,41 \pm 1,08 \%$.
\end{abstract}

Kata kunci: Hemispherical Photgraphy, Kerapatan, Mangrove, Tutupan Kanopi

\section{Compotition and Mangrove Canopy Cover in Bakauheni Waters, South Lampung Regency}

ABSTRACT: The health condition of mangrove vegetation on land and small islands is very important in maintaining the balance of coastal and marine ecosystems. Differences in mangrove area conditions can affect the dynamics of changes in vegetation and mangrove canopy cover. This study aims to analyze the structure, composition and cover of mangrove canopies in Bakauheni Waters, South Lampung Regency. The method used in this research is descriptive method. Determination of the point or sampling station using purposive sampling method. The method of collecting mangrove vegetation data using plot sampling method and mangrove canopy cover data collection using hemispherical photography method. This research was conducted in 4 locations, namely Kramat Village (DK), Muara Bakau Village (DMB), Rimau Balak Island (PRB), and Kandang Balak Island (PKB) consisting of 4 research stations. The results showed that the Bakauheni Waters area which consisted of 4 research sites found 14 mangrove species inside the plot and outside the research plot. Mangrove density values range from 966-1634 ind/ha. The value of Diversity Index ( $\left.H^{\prime}\right)$ and Uniformity $\left(J^{\prime}\right)$ in the study location is included in the low category. The percentage yield of mangrove canopy cover including the dense category ranges $72.04 \pm 13.18 \%-86.41 \pm 1.08 \%$.

Keywords: Hemispherical Photgraphy, Density, Mangrove, Canopy Cover

\section{PENDAHULUAN}

Vegetasi mangrove adalah komunitas tumbuhan-tumbuhan tropis yang berada di daerah tepi pantai yang memiliki kemampuan adaptasi pada perairan bersalinitas tinggi di wilayah intertidal yang dipengaruhi oleh pasang surut air laut (Supriharyono, 2009). Sebagai suatu ekosistem khas wilayah pesisir, ekosistem mangrove memiliki banyak fungsi dan manfaat dalam menunjang keberlangsungan 
makhluk hidup dan ekosistem terkait (Nurdin et al., 2015). Keanekaragaman vegetasi mangrove merupakan hal yang sangat penting dalam mempertahankan kekayaan genetik suatu ekosistem (Macintosh, 2002). Hutan mangrove memiliki peranan yang sangat penting bagi kelestarian ekosistem di daerah pesisir, baik secara ekologi, fisik, dan sumber daya ekonomi (Hogarth, 2007).

Secara fisik, hutan mangrove berfungsi sebagai mitigasi bencana seperti pelindung pantai dari pengaruh gelombang laut. Mangrove juga berperan sebagai perangkap sedimen, sehingga dapat mempercepat akresi daratan karena mangrove mampu mengembangkan wilayahnya ke arah laut, sehingga terjadi proses pembentukan lahan baru (Noor, 2006). Selain itu, fungsi ekologi hutan mangrove sangat besar yaitu sebagai pendaur hara, menyaring dan menangkap bahan pencemar, sebagai tempat berlindung, berpijah dan pembesaran bagi berbagai jenis ikan, udang, krustasea, kerang, burung, dan fauna lain serta mendukung produktivitas perikanan pesisir (Nybakken, 1992). Manfaat sumber daya ekonomi dari hutan mangrove meliputi bahan kayu konstruksi bangunan, kayu bakar, dan bubur kertas (pulp) dari spesies Rhizophora mucronata, kemudian dijadikan aneka olahan makanan dan minuman berbahan mangrove dari spesies Bruguiera gymnorrhiza dan Sonneratia caseolaris serta budidaya perikanan (Setyawan, 2006).

Kawasan Perairan Bakauheni yang secara administratif termasuk dalam wilayah Kabupaten Lampung Selatan, Provinsi Lampung, terdiri dari wilayah daratan Pulau Sumatera dan gugusan pulau-pulau kecil. Pada perairan Bakauheni ini memiliki tiga ekosistem pesisir berbeda yang saling berhubungan satu sama lain, seperti ekosistem terumbu karang, ekosistem lamun dan ekosistem mangrove. Kondisi ekosistem mangrove di Perairan Bakauheni merupakan mangrove yang tumbuh secara alami dan baik tanpa bantuan manusia, hal ini diperkuat dari keterangan masyarakat setempat bahwa belum ada kegiatan penanaman mangrove di Perairan Bakauheni, Lampung Selatan, Provinsi Lampung.

Ekosistem mangrove di Perairan Bakauheni tersebar di wilayah daratan Pulau Sumatera dan pulau - pulau kecil yang sangat penting dalam menjaga keseimbangan ekosistem pesisir dan laut. Perbedaan kondisi wilayah mangrove diduga dapat mempengaruhi dinamika perubahan vegetasi dan tutupan kanopi mangrove. Terbatasnya informasi tentang potensi dan kondisi ekosistem mangrove di Perairan Bakauheni merupakan salah satu faktor kelemahan dalam pengelolaan ekosistem mangrove di wilayah ini. Maka dari itu, perlu dilakukan kegiatan inventarisasi ekosistem mangrove dengan analisis vegetasi dan tutupan kanopi mangrove secara komprehensif yang belum pernah dilakukan sebagai dasar pemantauan dan pengelolaan kesehatan ekosistem mangrove secara berkelanjutan.

\section{MATERI DAN METODE}

Penelitian ini dilaksanakan pada bulan September 2019 di Perairan Bakauheni, Kabupaten Lampung Selatan, Provinsi Lampung. Lokasi penelitian dibagi dalam empat stasiun pengamatan yaitu Desa Kramat (DK), Desa Muara Bakau (DMB), Pulau Rimau Balak (PRB), dan Pulau Kandang Balak (PKB). Materi dalam penelitian ini adalah vegetasi mangrove yang terdiri dari pohon, anakan (sapling), semai (seedling) dan tutupan kanopi mangrove di Perairan Bakauheni. Pengambilan data parameter lingkungan seperti suhu air, suhu udara, salinitas dan $\mathrm{pH}$ diperlukan untuk menunjang keakuratan data. Pengamatan jenis substrat pada lokasi penelitian dilakukan untuk mengetahui pengaruh jenis substrat terhadap susunan jenis dan kerapatan vegetasi mangrove yang hidup di atasnya.

Metode yang digunakan dalam penelitian ini adalah metode deskriptif. Metode deskriptif merupakan salah satu cara untuk memperoleh fakta - fakta dari gejala yang ada dengan mencari data secara faktual, sistematis, dan akurat (Nazir, 2005). Metode deskriptif yang dipilih adalah metode survey. Metode survey merupakan metode pengumpulan data dengan mengambil sebagian data dari wilayah tertentu. Metode tersebut dipilih karena penelitian ini bertujuan untuk mendapatkan gambaran dan sifat populasi mangrove yang diambil dari sebagian populasi mangrove sehingga dapat diasumsikan mewakili seluruh populasi mangrove di Perairan Bakauheni, Kabupaten Lampung Selatan Provinsi Lampung.

Penentuan titik atau stasiun sampling dengan menggunakan metode purposive sampling. Metode purposive sampling merupakan metode penentuan stasiun sampling dengan melihat 
pertimbangan kondisi daerah penelitian didasarkan atas ciri - ciri atau sifat - sifat populasi yang termasuk kedalam anggota sampel dan harus benar mengetahui bahwa sampel yang digunakan dalam penelitian ini telah mewakili kondisi ekosistem mangrove (Hadi, 1980).

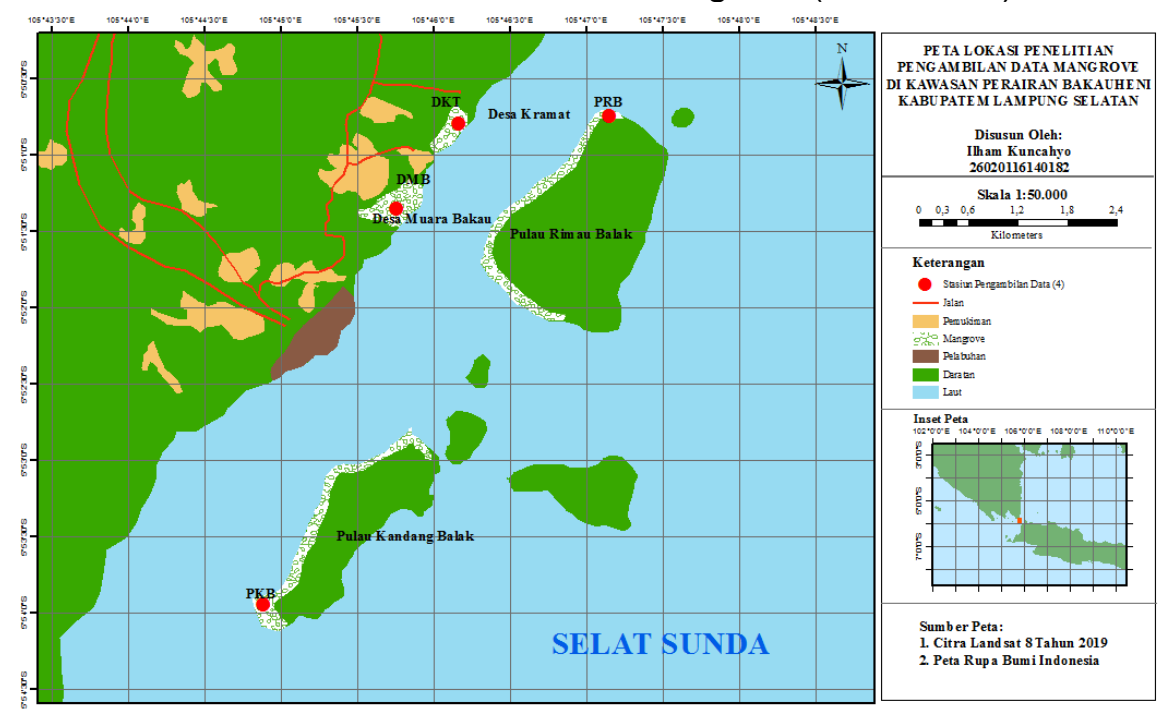

Gambar 1. Lokasi Penelitian di Perairan Bakauheni, Lampung

Penentuan titik dilakukan sebelum melakukan pengambilan data lapangan. Penentuan dan pertimbangan dilakukan dengan pengamatan melalui citra satelit, dan setelah ditentukan titiknya dilakukan survey lapangan pendahuluan (ground check). Kegiatan survey lapangan berfungsi untuk memastikan bahwa lokasi tersebut merupakan ekosistem mangrove dan layak untuk dilakukan penelitian atau tidak. Perekaman koordinat lokasi pengambilan sampel menggunakan Global Positioning System (GPS). Lokasi pengambilan data lapangan diharapkan dapat mewakili kategori ekosistem mangrove yang memiliki kerapatan padat, sedang, dan jarang. Berdasarkan hasil survey tersebut keberadaan mangrove di lokasi penelitian berada pada 4 stasiun yaitu di Desa Kramat (DK), Desa Muara Bakau (DMB), Pulau Rimau Balak (PRB), dan Pulau Kandang Balak (PKB) (Gambar 1). Masing - masing stasiun dilakukan penggelaran plot yang dilakukan 3 kali pengulangan untuk pengambilan data.

Metode pengambilan data vegetasi mangrove dilakukan dengan mengacu pada (Dharmawan dan Pramudji, 2017) yaitu dengan metode plot sampling. Sampel diambil secara acak terstratifikasi, dimana hasil dari survey pendahuluan dipilih titik pengambilan sampel, yang diharapkan mewakili dari kondisi masing - masing lokasi. Metode ini dilakukan pengambilan data berupa keliling atau diameter pada pohon, anakan (sapling), dan semai (seedling) mangrove yang berada didalam plot ukuran 10 $\mathrm{m} \times 10 \mathrm{~m}$ yang dilakukan tiga kali pengulangan dengan menggunakan tali transek dan plot berbentuk bujur sangkar yang sejajar dengan garis pantai.

Identifikasi spesies vegetasi mangrove dilakukan langsung di lapangan dengan mengacu pada Kitamura et al., (1997), dan Giesen et al. (2006). Jika terdapat keragu - raguan dalam mengidentifikasi spesies tertentu, maka diambil sampel meliputi daun, cabang, bunga, dan buah untuk dilakukan proses herbarium dan diidentifikasi lebih lanjut dengan mengacu pada Tomlinson (1994).

Pengambilan data pohon dilakukan dalam plot ukuran $10 \mathrm{~m} \times 10 \mathrm{~m}$ dengan diameter batang diukur pada ketinggian setinggi dada (Diameter at Breast Height) (DBH) atau $\pm 1,3 \mathrm{~m}$. Kategori pohon yang diukur memiliki DBH (diameter $\geq 4 \mathrm{~cm}$ atau keliling batang $\geq 16 \mathrm{~cm}$ ) meliputi jumlah tegakan mangrove, diameter pohon, spesies pohon, dan distribusi jenis dalam plot (Dharmawan dan Pramudji, 2017). Menurut Pribadi (1998), sampel anakan (sapling) diambil didalam plot ukuran $10 \mathrm{~m} \times 10 \mathrm{~m}$ dengan diameter batang $1<\mathrm{DBH}<4 \mathrm{~cm}$ dan tingginya $>1 \mathrm{~m}$. Data yang diambil berupa jenis dan diameter batang. Menurut Dharmawan dan Pramudji (2017), data semai (seedling) dilakukan pada plot ukuran $10 \mathrm{~m}$ x $10 \mathrm{~m}$ dan ketinggian $<1 \mathrm{~m}$.

Data yang diambil dalam plot ukuran $10 \mathrm{~m} \times 10 \mathrm{~m}$ meliputi spesies, keliling atau diameter 
batang, dan tinggi pohon. Setiap data yang diperoleh dicatat dalam data sheet yang telah disiapkan pada kertas tahan air. Pencatatan data hasil pengukuran dilakukan berdasarkan data sheet yang ada. Data yang diambil tersebut kemudian dianalisis untuk dihitung nilai indeksnya, yaitu Kerapatan (K), Frekuensi (F), Basal Area (BA), Frekuensi Relatif (FR), Kerapatan Relatif (KR), Dominansi Relatif (DR), dan Indeks Nilai Penting (INP).

Tutupan kanopi mangrove dihitung dengan menggunakan metode hemispherichal photography dibutuhkan kamera lensa fish eye dengan sudut pandang $180^{\circ}$ atau penggunaan kamera handphone. Pada penelitian ini mengacu pada metode penelitian fotografi yang dilakukan oleh Dharmawan dan Pramudji (2017), yang menyatakan bahwa setiap plot dibagi menjadi beberapa kuadran sesuai dengan keadaan hutan mangrove dimana setiap kuadran diambil satu kali foto berdasarkan persyaratan yang sudah ditentukan, kemudian dilakukan pengulangan sebanyak satu kali. Pengambilan foto dilakukan dengan menggunakan kamera depan dengan resolusi 4 megapixel. Kelemahan dalam metode hemispherichal photography yaitu dalam pengambilan foto tidak dapat dilakukan di bawah sinar matahari yang terang dapat mengakibatkan terjadinya penyebaran radiasi sinar yang menghalangi kanopi pohon.

Setiap plot $10 \mathrm{~m}$ x $10 \mathrm{~m}$ dibagi menjadi beberapa subplot atau kuadran posisi pengambilan foto tergantung dari kondisi hutan mangrove di lokasi penelitian. Posisi pengambilan data dengan menggunakan kamera yang disejajarkan dengan tinggi dada, serta tegak lurus menghadap langit.

Hutan mangrove dengan tutupan kanopi yang rendah, atau tutupan kanopi tidak beraturan, atau banyak penebangan, maka dilakukan pengambilan foto sebanyak 9 kali dalam setiap plot. Hutan mangrove dengan tutupan kanopi yang tinggi, kondisinya ada beberapa penebangan atau kondisi tutupan yang tidak sempurna menutup seluruh plot, maka dilakukan pengambilan foto sebanyak 5 foto pada setiap plot. Hutan mangrove dengan tutupan kanopi yang rapat, menutupi seluruh plot, kondisi masih dengan alami dan tegakan pohon tinggi, maka dilakukan pengambilan foto sebanyak 4 foto pada setiap plot.

Konsep dari analisis ini adalah pemisahan pixel langit yang diasumsikan sebagai warna putih dan tutupan kanopi vegetasi sebagai warna hitam, sehingga persentase jumlah pixel tutupan kanopi mangrove dapat dihitung dalam analisis gambar biner (Chianucci, Chiavetta \& Cutini, 2014). Foto dianalisis dengan menggunakan software ImageJ dan Microsoft Excel untuk dihitung persentase tutupan mangrove.

$$
\% \text { tutupan (cover) mangrove }=\frac{P 255}{\sum^{P}} \times 100 \%
$$

Kondisi rata-rata tutupan kanopi mangrove dikategorikan menjadi tiga kelompok, yaitu padat (>75\%) dengan kerapatan $\geq 1500$ ind/ha; sedang (antara 50\% - 75\%) dengan kerapatan $1000-1500$ ind/ha dan jarang $(<50 \%)$ dengan kerapatan $<1000$ ind/ha, berdasarkan Standar Baku Kerusakan Hutan Mangrove Keputusan Menteri Lingkungan Hidup No. 201 tahun 2004.

\section{HASIL DAN PEMBAHASAN}

Hasil penelitian ditemukan 14 spesies mangrove terdapat di dalam dan di luar plot lokasi penelitian pengambilan data. Komposisi mangrove yang ditemukan di lokasi penelitian terdiri atas 3 komponen yaitu, mayor, minor, dan asosiasi. Ditemukan pada lokasi penelitian terdapat 4 famili termasuk komponen mayor, 4 famili termasuk komponen minor dan 1 famili termasuk komponen asoisasi. Pada penelitian ini didominasi oleh famili Rhizophoraceae karena ditemukan 5 spesies dari total 14 spesies yang ditemukan. Selanjutnya ditemukan 2 spesies dari famili Meliaceae. Famili Euphorbiaceae, Sonneratiaceae, Combretaceae, Rubiaceae, Malvaceae, Lythraceae, dan Arecaceae masing - masing hanya ditemukan 1 spesies.

Berdasarkan banyaknya hasil spesies mangrove yang ditemukan di empat stasiun penelitian yang berada di Perairan Bakauheni karena vegetasi mangrove yang hidup berada di pesisir dan pulau - pulau kecil yang merupakan lokasi yang baik untuk pertumbuhan dan perkembangan mangrove karena wilayah perairan masih dipengaruhi oleh pasang surut. Vegetasi di kawasan pesisir termasuk ke dalam jenis fringing mangrove forest yang merupakan tipe mangrove yang tumbuh dan berkembang disepanjang garis pantai yang menerima pasang surut air laut setiap hari dan peka terhadap erosi oleh pengaruh energi gelombang. Sedangkan untuk mangrove yang hidup di pulau - 
pulau kecil termasuk kedalam jenis overwash mangrove forest yang merupakan wilayah pulau kecil yang selalu terendam oleh pasang surut air laut. Walaupun habitat hutan mangrove bersifat khusus, namun masing - masing jenis tumbuhan memiliki kisaran ekologi tersendiri, sehingga kondisi ini menyebabkan terbentuknya berbagai macam komunitas dan zonasi. Munculnya fenomena zonasi yang terjadi pada hutan mangrove tersebut sangat berkaitan dengan beberapa faktor, salah satunya tipe tanah. Pengaruh tipe tanah atau substrat pada penelitian ini misalnya pada tanah lumpur berpasir akan tumbuh dan didominasi oleh spesies Rhizophora apiculata yang tumbuh berdampingan dengan spesies mangrove lainnya.

Tabel 1. Komposisi spesies mangrove yang ditemukan di Desa Kramat, Desa Muara Bakau, Pulau Rimau Balak dan Pulau Kandang Balak.

\begin{tabular}{|c|c|c|}
\hline Famili dan Spesies Mangrove & Nama Lokal $^{*}$ & Kategori \\
\hline $\begin{array}{l}\text { Rhizophoraceae } \\
\text { Rhizophora apiculata Blume } \\
\text { Rhizophora mucronata Lam. } \\
\text { Rhizophora lamarckii Montr. } \\
\text { Bruguiera gymnorrhiza (L.) Lam } \\
\text { Ceriops tagal C.B.Rob. }\end{array}$ & $\begin{array}{l}\text { Jangkah } \\
\text { Bakau } \\
\text { Bakau } \\
\text { Lindur } \\
\text { Mentigi }\end{array}$ & $\begin{array}{l}\text { Mayor } \\
\text { Mayor } \\
\text { Mayor } \\
\text { Mayor } \\
\text { Mayor }\end{array}$ \\
\hline $\begin{array}{l}\text { Arecaceae } \\
\text { Nypa fruticans Wurmb. } \\
\text { Sonneratiaceae } \\
\text { Sonneratia alba J. Sm. }\end{array}$ & $\begin{array}{l}\text { Nipah } \\
\text { Bogem }\end{array}$ & $\begin{array}{l}\text { Mayor } \\
\text { Mayor }\end{array}$ \\
\hline $\begin{array}{l}\text { Combretacea } \\
\text { Lumnitzera racemosa Willd. }\end{array}$ & Kedukduk & Mayor \\
\hline $\begin{array}{l}\text { Rubiaceae } \\
\text { Scyphiphora hydrophyllacea Gaertn. F. }\end{array}$ & Cingam & Minor \\
\hline $\begin{array}{l}\text { Meliaceae } \\
\text { Xylocarpus granatum Koen. } \\
\text { Xylocarpus moluccensis (Lam.) R. Roem. }\end{array}$ & $\begin{array}{l}\text { Nyirih } \\
\text { Nyirih }\end{array}$ & Minor \\
\hline $\begin{array}{l}\text { Euphorbiaceae } \\
\text { Excoecaria agallocha L. }\end{array}$ & Buta - buta & Minor \\
\hline $\begin{array}{l}\text { Lythraceae } \\
\text { Pemphis acidula S.R. Forst \& G. Forst. }\end{array}$ & Setigi & Minor \\
\hline $\begin{array}{l}\text { Malvaceae } \\
\text { Thespesia populnea (L) Sol. Ex Corr. }\end{array}$ & Waru Laut & Asosiasi \\
\hline
\end{tabular}

Sumber : *Penamaan nama lokal berdasarkan Kitamura (1997)

Jumlah spesies mangrove di lokasi penelitian lebih kecil dibandingkan penelitian yang dilakukan Rahman (2019) di Teluk Serewe, Kabupaten Lombok Timur melaporkan bahwa terdapat 7 famili yang terdiri dari 14 spesies mangrove yang terdapat di dalam plot penelitian. Tetapi lebih tinggi jika dibandingkan dengan penelitian yang dilakukan oleh Seran (2019) di Pantai Paradiso, Kota Kupang yang terdapat 2 famili yang terdiri dari 2 spesies mangrove yaitu Avicennia marina dan Rhizophora $s p$. Hal ini memungkinkan karena vegetasi mangrove di wilayah Perairan Bakauheni terletak di pesisir dan pulau - pulau kecil yang merupakan daerah pasang surut air laut yang menyebabkan terjadinya beberapa perubahan faktor lingkungan seperti suhu dan salinitas. Oleh karena itu, hanya beberapa jenis tumbuhan mangrove yang memiliki daya toleransi yang tinggi terhadap lingkungan yang mampu bertahan hidup dan berkembang. Kondisi yang terjadi menyebabkan rendahnya keanekaragaman jenis, namun kepadatan populasi masing - masing jenis mangrove tinggi.

Berdasarkan hasil analisis vegetasi mangrove diketahui bahwa nilai kerapatan vegetasi mangrove untuk kategori pohon di Desa Kramat adalah 1634 ind/ha pada Stasiun DK, Desa Muara Bakau berkisar 1434 ind/ha pada Stasiun DMB, Pulau Rimau Balak berkisar 1400 ind/ha pada Stasiun PRB, dan Pulau Kandang Balak berkisar 966 ind/ha pada Stasiun PKB. Spesies mangrove 
yang memiliki kerapatan tertinggi pada Stasiun DK, DMB, dan PRB yaitu Rhizophora apiculata. Kemudian, pada Pulau Kandang Balak memiliki kerapatan spesies mangrove tertinggi yaitu Rhizophora lamarckii. Genus Rhizophora mendominasi pada kategori pohon dan memiliki kerapatan tertinggi di seluruh stasiun penelitian. Kondisi ini disebabkan karena genus mangrove ini memiliki toleransi pertumbuhan terhadap kondisi lingkungan perairan, terutama terhadap kondisi substrat lingkungan dan penyebaran bijinya yang sangat luas. Hal ini sesuai dengan pernyataan odum (1993) bahwa kelompok yang dominan pada suatu ekosistem mangrove adalah jenis bakau dari famili Rhizophoraceae.

Secara umum kisaran nilai kerapatan vegetasi mangrove kategori pohon di Perairan Bakauheni yang tersebar di empat lokasi penelitian memiliki nilai berkisar 966-1634 ind/ha, hasil ini lebih besar dibandingkan dengan kerapatan di Kabupaten Bekasi (Marsudi, 2018) yang mempunyai kerapatan 480 ind/ha. Perbedaan kerapatan vegetasi mangrove di setiap wilayah dikarenakan adanya pengaruh kondisi lingkungan perairan, jenis substrat, dan aktivitas manusia di sekitar vegetasi mangrove tersebut. Berdasarkan hasil kerapatan, menunjukkan bahwa di Perairan Bakauheni termasuk kedalam kategori mangrove yang memiliki kerapatan yang sedang sampai padat dengan kerapatan sedang 1000-1500 ind/ha dan padat $>1500$ ind/ha. Berbanding terbalik dengan lokasi penelitian oleh Marsudi (2018) yang memiliki kerapatan jarang dan kondisi rusak $<1000$ ind/ha, berdasarkan Keputusan Menteri Lingkungan Hidup No. 201 Tahun 2004 mengenai kriteria baku kerusakan mangrove.

Desa Kramat dan Desa Muara Bakau berada di kawasan pesisir Pulau Sumatera bagian selatan, sedangkan Pulau Rimau Balak dan Pulau Kandang Balak merupakan pulau - pulau kecil yang berada di sekitar perairan bakauheni. Berdasarkan hasil kerapatan di Stasiun DK dan DMB memiliki pertumbuhan mangrove yang baik dan memiliki kerapatan sedang hingga padat. Stasiun PRB memiliki kriteria baik dan kerapatan sedang, sedangkan Stasiun PKB memiliki kriteria rusak dan kerapatan jarang. Hal ini menunjukkan bahwa pertumbuhan mangrove yang didominasi oleh genus Rhizophora di kawasan pesisir tumbuh alami dengan baik karena minim aktivitas penebangan pohon mangrove oleh manusia. Faktor lingkungan seperti substrat, salinitas, suhu, dan regenerasi mangrove baru yang mendukung untuk pertumbuhan dan perkembangan mangrove sehingga memiliki kerapatan yang tinggi. Vegetasi mangrove yang hidup dan tumbuh di pulau - pulau kecil tumbuh dengan alami tetapi memiliki kondisi yang cukup ekstrim seperti pengaruh gelombang yang besar dan arus laut yang mempengaruhi kondisi lingkungan vegetasi mangrove. Hal ini didukung oleh pernyataan Subur (2017) bahwa mangrove akan tumbuh dengan baik pada wilayah yang terlindung, perairan yang tenang, kondisi substrat dan lingkungan yang stabil, sedangkan vegetasi mangrove yang tumbuh di pulau - pulau kecil relatif terbuka terhadap gelombang dan arus air laut.

Tabel 2 menunjukkan nilai Indeks Keanekaragaman Shannon - Wienner $\left(H^{\prime}\right)$ pada lokasi penelitian di Perairan Bakauheni yang tersebar di Desa Kramat, Desa Muara Bakau, Pulau Rimau Balak, dan Pulau Kandang Balak tergolong dalam kategori rendah, dimana pada Desa Kramat nilai $\left(H^{\prime}\right)$ bernilai 0,30, Desa Muara Bakau nilai $\left(H^{\prime}\right)$ bernilai 0,35, Pulau Rimau Balak bernilai 0,53 dan Pulau Kandang Balak nilai $\left(H^{\prime}\right)$ bernilai 0,45 . Hasil nilai Indeks Keanekaragaman sama rendahnya dengan peneltiian yang dilakukan oleh Rosadi, Ario \& Pribadi (2018) di Kabupaten Sampang yaitu 0,45 . Rendahnya nilai Indeks Keanekaragaman $\left(H^{\prime}\right)$ dikarenakan jumlah individu tiap spesies (n) pada setiap stasiun yang ditemukan sedikit. Hal menunjukkan bahwa keanekaragaman jenis suatu komunitas akan rendah jika komunitas itu disusun oleh sedikit jenis dan ada jenis yang dominan di wilayah pengambilan data tersebut. Sebaliknya, suatu komunitas memiliki nilai keanekaragaman jenis yang tinggi, jika komunitas itu disusun oleh banyak jenis dan tidak ada jenis yang mendominasi. Persaingan hidup antar spesies mangrove pada kategori semai atau anakan tidak dapat bertahan dan sulit beradaptasi dengan lingkungannya sehingga tumbuhan akan mati. Sedangkan tumbuhan lainnya yang mampu beradaptasi dengan lingkungannya akan tetap mengalami pertumbuhan menjadi tumbuhan dewasa.

Nilai Indeks Keseragaman (J') pada lokasi penelitian di Perairan Bakauheni, Kabupaten Lampung Selatan yang tersebar di empat stasiun yaitu Stasiun DK, DMB, PRB, dan PKB tergolong dalam kategori rendah, dimana pada Desa Kramat memiliki nilai ( $\mathrm{J}$ ') bernilai 0,05, Desa Muara Bakau nilai (J') yaitu 0,04, Pulau Rimau Balak nilai (J') yaitu 0,07, dan Pulau Kandang Balak nilai 
(J') yaitu 0,07. Rendahnya Indeks Keseragaman di lokasi penelitian disebabkan karena adanya satu atau beberapa spesies mangrove yang mendominasi pertumbuhannya di semua lokasi, sehingga berpengaruh terhadap nilai keseragaman. Faktor substrat di lokasi penelitian juga dapat mempengaruhi pertumbuhan spesies tertentu sehingga dapat tumbuh dan hidup dengan baik serta mendominasi di wilayah ini. Nilai Keseragaman ( $\left.\mathrm{J}^{\prime}\right)$ di lokasi penelitian ini lebih rendah jika dibandingkan dengan penelitian yang dilakukan oleh Renta et al. (2016) di Kabupaten Pemalang, Provinsi Jawa Tengah yaitu bernilai 0,17 dan Ardiansyah et al. (2012) di Kabupaten Nunukan, Provinsi Kalimantan Timur yaitu bernilai 0,25. Tingginya Indeks Keseragaman (J') di lokasi penelitian tersebut disebabkan meratanya dominansi spesies mangrove, antara fase pohon dan anakan di perairan tertentu sehingga tidak ada dominansi satu spesies mangrove yang hidup di sekitar lokasi penelitian tersebut.

Nilai Indeks Keseragaman (J') di Lokasi Penelitian pada empat stasiun yang berada di wilayah Perairan Bakauheni berkisar antara 0,04-0,07. Nilai Indeks Keseragaman (J') pada Lokasi Penelitian ini lebih tinggi nilainya jika dibandingkan dengan penelitian Murtiyoso (2018) di Pulau Nyamuk dan Pulau Parang Kabupaten Jepara yaitu kisaran sebesar 0,0095-0,0972. Hal ini menunjukkan bahwa semakin rendah indeks keseragaman suatu komunitas berarti bahwa kondisi lingkungan makin tidak stabil. Rendahnya nilai keseragaman menunjukkan bahwa kondisi mangrove dalam keadaan tertekan. Sebaliknya, semakin seragam penyebaran individu antar spesies maka keseimbangan ekosistem akan semakin meningkat.

Persentase tutupan kanopi mangrove berdasarkan Tabel 3, secara keseluruhan di Perairan Bakauheni berkisar $72,04 \pm 13,18 \%-86,41 \pm 1,08 \%$ dari 4 stasiun penelitian, tiga stasiun berstatus padat yaitu Stasiun DK, DMB, dan PKB, sementara Stasiun PRB berstatus sedang. Persentase tertinggi terdapat pada Stasiun DMB dengan status padat yang memiliki nilai tutupan $86,41 \pm 1,08 \%$ dan persentase terendah pada Stasiun PRB dengan tutupan $72,04 \pm 13,18 \%$ dengan status sedang berdasarkan Keputusan Menteri Lingkungan Hidup No. 201 Tahun 2004.

Hasil penelitian persentase tutupan kanopi mangrove ini lebih tinggi dibandingkan dengan penelitian di Kabupaten Brebes (Ningrum, 2019) dengan hasil tutupan berkisar 63,05-84,63\% dan hasil penelitian di Kabupaten Jepara (Mauludin et al., 2017) yang memiliki tutupan berkisar 58,15 $80,41 \%$. Kondisi vegetasi mangrove di Kabupaten Brebes yang didominasi oleh spesies Avicennia marina dan Kabupaten Jepara yang didominasi oleh spesies Rhizophora apiculata memiliki persentase tutupan kanopi mangrove dan kondisi kerapatan mangrove yang rendah. Substrat berpasir, berlumpur dan salinitas yang cukup tinggi merupakan habitat alami untuk jenis Avicennia marina dan Rhizophora apiculata.

Tabel 2. Indeks Keanekaragaman Shannon - Wienner (H') dan Keseragaman (J') pada kategori pohon

\begin{tabular}{lllll}
\hline Stasiun & H'$^{\prime}$ & Kategori & J' & Kategori \\
\hline DK & 0,30 & Rendah & 0,05 & Rendah \\
DMB & 0,35 & Rendah & 0,04 & Rendah \\
PRB & 0,53 & Rendah & 0,07 & Rendah \\
PKB & 0,45 & Rendah & 0,07 & Rendah \\
\hline
\end{tabular}

Tabel 3. Rata - rata persentase tutupan kanopi pohon dan status kerapatan pada 4 stasiun pemantauan mangrove di Perairan Bakauheni, Lampung।

\begin{tabular}{lcccc}
\hline \multicolumn{1}{c}{ Lokasi } & Stasiun & \% Tutupan \pm SD & Kerapatan (ha) & Status $^{*}$ \\
\hline Desa Kramat & DK & $81,86 \pm 3,76$ & 1634 & Baik dan Padat \\
Desa Muara Bakau & DMB & $86,41 \pm 1,08$ & 1434 & Baik dan Padat \\
Pulau Rimau Balak & PRB & $72,04 \pm 13,18$ & 1400 & Baik dan Sedang \\
Pulau Kandang Balak & PKB & $78,57 \pm 6,87$ & 966 & Baik dan Padat \\
\hline
\end{tabular}

Sumber : Keputusan Menteri Lingkungan Hidup No. 201 Tahun 2004. 
Berdasarkan hasil penelitian, Stasiun DK dan PKB didominasi oleh Rhizophora lamarckii, sedangkan Stasiun DMB dan PRB didominasi oleh spesies mangrove Rhizophora apiculata. hal ini menunjukkan bahwa jenis Rhizophora sp. dikenal sebagai jenis mangrove yang memiliki morfologi daun yang lebar, ukuran daun yang bisa mencapai 9-20 cm, dengan demikian persen tutupan kanopi mangrove yang dihasilkan juga akan besar. Kanopi pohon berperan seperti payung, membagi dan memotong persebaran sinar matahari serta hujan.

Minimnya sinar matahari dapat mempengaruhi pertumbuhan semai pohon. Semakin tinggi pohon maka akan semakin baik juga pertumbuhan pohonnya. Cahaya matahari dalam proses fotosintesis dan respirasi serta pertumbuhan daun. Menurut Ayensu (1980) menambahkan bahwa lapisan paling atas hutan mendapatkan intensitas sinar matahari paling tinggi, angin kencang, dan variasi suhu serta kelembaban setiap harinya.

Selain itu distribusi diameter batang pohon dan ketinggian pohon mangrove menjadi salah satu faktor tinggi rendahnya persentase tutupan kanopi mangrove. Stasiun DMB memiliki persentase tutupan kanopi mangrove tertinggi, karena jarak individu mangrove yang ada di lokasi penelitian saling berdekatan atau padat. Sementara, Stasiun PRB memiliki nilai persentase tutupan kanopi mangrove terendah, hal ini karena jumlah individu mangrove yang ditemukan di lokasi penelitian lebih sedikit atau jarang. Hal ini yang menyebabkan celah pada tutupan kanopi pohon, karena letak individu mangrove berjauhan. Tomlinson (1994) menambahkan faktor lingkungan seperti kerusakan oleh gelombang laut, tingkat pencahayaan, dan predasi dapat mempengaruhi pembentukan tutupan kanopi mangrove.

\section{KESIMPULAN}

Berdasarkan hasil penelitian ini dapat disimpulkan bahwa di Stasiun Desa Kramat (DK), Desa Muara Bakau (DMB), Pulau Rimau Balak (PRB), dan Pulau Kandang Balak (PKB) pada Perairan Bakauheni, Kabupaten Lampung Selatan, Provinsi Lampung ditemukan 14 spesies mangrove. Nilai Kerapatan didapatkan data berkisar 966-1634 ind/ha didominasi oleh spesies Rhizophora sp.

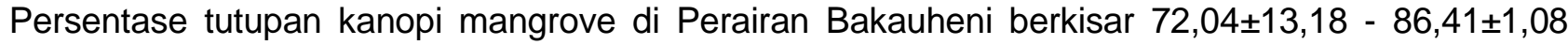
termasuk dalam kategori padat.

\section{DAFTAR PUSTAKA}

Ardiansyah, W.I., Pribadi, R. \& Soenardjo, N., 2012. Struktur dan komposisi vegetasi mangrove di kawasan pesisir Pulau Sebatik, Kabupaten Nunukan, Kalimantan Timur. Journal of Marine Research, 1(2):203-215.

Ayensu, E.S. 1980. Jungles. Smithsonian Institution. Washington

Chianucci, F., Chiavetta, U. \& Cutini, A. 2014. The estimation of canopy attributes from digital cover photography by two different image analysis methods. IForest, 7(4):255- 259.

Dharmawan, I.W.E. \& Pramudji. 2017. Panduan Pemantauan Komunitas Mangrove : Edisi 2. COREMAP-CIT, Pusat Penelitian Oseanografi, LIPI. Jakarta.

Giesen, W., Wulffraat, S., Zieren, M. \& Scholten, L. 2007. Mangrove guidebook for southeast asia, FAO and Wetland Internasional. 189p

Hadi, S. 1980. Metodologi Research. Yogyakarta: Yayasan Penerbit Fakultas Psiokologi Universitas Gajah Mada.

Hogart, P.J. 2007. The Biology of Mangrove and Seagrass. New York

Kitamura, S.C. 1997. Buku Panduan Mangrove di Indonesia (Bali dan Lombok)

Macintosh, D.J. 2002. Preliminary assessment of the plant diversity and community ecology of the Sematan mangrove forest, Sarawak, Malaysia. Forest Ecology and Management. 166:111129.

Marsudi, B., Satjapradja, O. \& Salampessy, M.L. 2018. Komposisi Jenis Pohon Dan Struktur Tegakan Hutan Mangrove Di Desa Pantai Bahagia Kecamatan Muara Gembong Kabupaten Bekasi Provinsi Jawa Barat. Jurnal Belantara, 1(2):115-122.

Mauludin, M.R., Azizah, R., Pribadi, R. \& Suryono, S. 2017. Komposisi dan Tutupan Kanopi Mangrove di Kawasan Ujung Piring Kabupaten Jepara. Buletin Oseanografi Marina, 7(1):2936. 
Nazir, M. 2005. Metode Penelitian. Penerbit Ghalia, Bogor

Ningrum, A.F. 2019. Kajian Struktur Komposisi Dan Tutupan Kanopi Mangrove Dengan Metode Hemispherical Photography Di Desa Kaliwlingi Dan Sawojajar, Kabupaten Brebes, Jawa Tengah. Doctoral dissertation, Faculty of Fisheries and Marine Sciences

Noor, R.Y. 2006. Panduan Pengenalan Mangrove di Indonesia

Nurdin, N., Akbar, M. \& Patittingi, F. 2015. Dynamic of mangrove cover change with anthropogenic factors on small island, Spermonde Archipelago. Proc. of SPIE, 9638: 1-11.

Nybakken, J.W. 1992. Biologi Laut Suatu Pendekatan Ekologis. Alih bahasa oleh M. Eidman. Koesoebiono., D.G. Bengen., M.Hutomo., S.Sukardjo. PT. Gramedia PustakaUtama. Jakarta, Indonesia.

Odum. 1993. Dasar - Dasar Ekologi. Universitas Gajah Mada

Rahman, F.A. 2019. Komposisi Vegetasi Mangrove Berdasarkan Strata Pertumbuhan Di Teluk Sereweh, Kabupaten Lombok Timur, Nusa Tenggara Barat. Jurnal Pendidikan Biologi Dan Sains (Penbios), 4(02):53-61.

Renta, P.P., Pribadi, R., Zainuri, M. \& Utami, M.A.F. 2016. Struktur Komunitas Mangrove di Desa Mojo Kabupaten Pemalang Jawa Tengah. Jurnal Enggano, 1(2):1-10.

Rosadi, A., Ario, R. \& Pribadi, R.. 2018. Struktur Dan Komposisi Vegetasi Mangrove Di Kabupaten Sampang, Pulau Madura, Provinsi Jawa Timur. Journal of Marine Research, 7(3):212-218.

Seran, W. 2019. Struktur dan Komposisi Spesies Hutan Mangrove di Pantai Paradiso, Kota Kupang, NTT. Jurnal Agribisnis Perikanan. 12(1):34-42. DOI: 10.29239/j.agrikan.12.1.34-42

Setyawan, A.D \& Winarno, K. 2006. Pemanfaatan Langsung Ekosistem Mangroove di Jawa Tengah daan Penggunaan Lahan di Sekitarnya: Kerusakan dan Upaya Restorasinya. UNS. Surakarta.

Subur, R. 2017. Kapasitas Adaptif Ekosistem Mangrove Di Pulau-Pulau Kecil (Studi Di Gugus Pulau Guraici) Kabupaten Halmahera Selatan Provinsi Maluku Utara. Prosiding Seminar Nasional Kemaritiman Dan Sumber Daya Pulau-Pulau Kecil. 1(1):86-94.

Supriharyono, 2009. Konservasi Ekosistem Sumberdaya Hayati di Wilayah Pesisir dan Laut Tropis. Pustaka Pelajar. Yogyakarta.

Tomlinson, P.B. 1994. The Botany of Mangrove. Cambridge. New York 